BNL-114109-2017-JA

\title{
Synthetic Control of Crystallite Size of Silver Vanadium Phosphorous Oxide (Ag0.50VOPO4 • 1.9H2O): Impact on Electrochemistry
}

\author{
M. M. Huie, A. C. Marschilok, E. S. Takeuchi and K. J. Takeuchi
}

Submitted to Journal of the Electrochemical Society

April 12, 2017

Energy and Photon Sciences Directorate

Brookhaven National Laboratory

\author{
U.S. Department of Energy \\ USDOE Office of Science (SC), \\ Basic Energy Sciences (BES) (SC-22)
}

Notice: This manuscript has been co-authored by employees of Brookhaven Science Associates, LLC under Contract No. DE-SC0012704 with the U.S. Department of Energy. The publisher by accepting the manuscript for publication acknowledges that the United States Government retains a non-exclusive, paid-up, irrevocable, world-wide license to publish or reproduce the published form of this manuscript, or allow others to do so, for United States Government purposes. 


\section{DISCLAIMER}

This report was prepared as an account of work sponsored by an agency of the United States Government. Neither the United States Government nor any agency thereof, nor any of their employees, nor any of their contractors, subcontractors, or their employees, makes any warranty, express or implied, or assumes any legal liability or responsibility for the accuracy, completeness, or any third party's use or the results of such use of any information, apparatus, product, or process disclosed, or represents that its use would not infringe privately owned rights. Reference herein to any specific commercial product, process, or service by trade name, trademark, manufacturer, or otherwise, does not necessarily constitute or imply its endorsement, recommendation, or favoring by the United States Government or any agency thereof or its contractors or subcontractors. The views and opinions of authors expressed herein do not necessarily state or reflect those of the United States Government or any agency thereof. 


\section{Synthetic Control of Crystallite Size of Silver Vanadium Phosphorous Oxide}

\section{$\left(\mathrm{Ag}_{0.50} \mathrm{VOPO}_{4} \cdot 1.9 \mathrm{H}_{2} \mathrm{O}\right)$ : Impact on Electrochemistry}

Matthew M. Huie ${ }^{\dagger}$, Amy C. Marschilok ${ }^{*,+, \neq}$, Esther S. Takeuchi ${ }^{*}, \neq, \#$, Kenneth J. Takeuchi ${ }^{*,+, \neq}$

${ }^{\dagger}$ Department of Materials Science and Engineering and ${ }^{\ddagger}$ Department of Chemistry, Stony Brook University, Stony Brook, New York, 11794, United States

\#Energy Sciences Directorate, Brookhaven National Laboratory, Upton, New York, 11973, United States

KEYWORDS. silver vanadium phosphorous oxide, lithium battery, crystallite size, conductivity Corresponding authors: amy.marschilok@stonybrook.edu (ACM), esther.takeuchi@stonybrook.edu(EST), kenneth.takeuchi.1@stonybrook.edu (KJT) 
ABSTRACT. This report describes a synthetic approach to control the crystallite size of silver vanadium phosphorous oxide, $\mathrm{Ag}_{0.50} \mathrm{VOPO}_{4} \cdot 1.9 \mathrm{H}_{2} \mathrm{O}$, and the impact on electrochemistry in lithium based batteries. $\mathrm{Ag}_{0.50} \mathrm{VOPO}_{4} \cdot 1.9 \mathrm{H}_{2} \mathrm{O}$ was synthesized using a stirred hydrothermal method over a range of temperatures. X-ray diffraction (XRD) was used to confirm the crystalline phase and the crystallite size sizes of $11,22,38,40,49$, and $120 \mathrm{~nm}$. Particle shape was plate-like with edges $<1$ micron to $>10$ microns. Under galvanostatic reduction the samples with $22 \mathrm{~nm}$ crystallites and $880 \mathrm{~nm}$ particles produced the highest capacity, 25\% more capacity than the $120 \mathrm{~nm}$ sample. Notably, the $11 \mathrm{~nm}$ sample resulted in reduced delivered capacity and higher resistance consistent with increased grain boundaries contributing to resistance. Under intermittent pulsing ohmic resistance decreased with increasing crystallite size from $11 \mathrm{~nm}$ to $120 \mathrm{~nm}$ implying that electrical conduction within a crystal is more facile than between crystallites and across grain boundaries. This systematic study of material dimension shows that crystallite size impacts deliverable capacity as well as cell resistance where both interparticle and intraparticle transport are important.

\section{INTRODUCTION}

Silver vanadium oxide (SVO), $\mathrm{Ag}_{2} \mathrm{~V}_{4} \mathrm{O}_{11}$, has been a premier cathode material for high power batteries, such as those used in implantable cardioverter defibrillators (ICDs).(1-3) SVO is a bimetallic crystalline material that shows two inherent properties: When paired with a lithium anode SVO provides multiple electron transfers which provides high energy content; and 2) $\mathrm{Ag}^{+}$ ions in SVO reduce to form conductive silver nanoparticles through a reduction-displacement reaction allowing for high cathode electrical conductivity facilitating power delivery. Other examples of bimetallic oxide and polyanion framework materials provide a similar opportunity 
for enhanced conductivity upon electrochemical reduction via in situ metal formation through reduction displacement including $\quad \mathrm{Ag}_{4} \mathrm{~V}_{2} \mathrm{O}_{6} \mathrm{~F}_{2},(4) \quad \mathrm{Ag}_{7} \mathrm{Fe}_{3}\left(\mathrm{P}_{2} \mathrm{O}_{7}\right)_{4},(5) \quad \mathrm{Ag}_{6} \mathrm{Mo}_{2} \mathrm{O}_{7} \mathrm{~F}_{3} \mathrm{Cl},(6)$ $\mathrm{AgFeO}_{2},(7,8), \mathrm{Cu}_{\mathrm{x}} \mathrm{V}_{2} \mathrm{O}_{5},(9) \mathrm{Cu}_{2.33} \mathrm{~V}_{4} \mathrm{O}_{11.21},(10)$ and silver vanadium phosphorous oxides $\left(\mathrm{Ag}_{\mathrm{w}} \mathrm{V}_{\mathrm{x}} \mathrm{P}_{\mathrm{y}} \mathrm{O}_{z}\right) \cdot(11)$

For the silver vanadium phosphorous oxides $\left(\mathrm{Ag}_{\mathrm{w}} \mathrm{V}_{\mathrm{x}} \mathrm{P}_{\mathrm{y}} \mathrm{O}_{\mathrm{z}}\right)$ material class, $\mathrm{Ag}^{0}$ formation via reduction-displacement upon initial electrochemical reduction can result in a 15,000-fold increase in cathode conductivity.(12) The rate of the discharge process significantly impacts whether the Ag extrusion and V reduction are sequential or concurrent (13), the distribution of silver within the cathode and the resulting electrode impedance where a faster rate of discharge resulted in non-homogeneous $\mathrm{Ag}^{0}$ formation in the cathode with more $\mathrm{Ag}^{+}$reduction near the current collector. $(14,15)$ At a slower rate the $\mathrm{Ag}^{0}$ was much more evenly distributed throughout the cathode resulting in improved charge transfer resistance and a more complete utilization of active material.

Several types of silver vanadium phosphorous oxides have been investigated as cathodes in lithium based batteries.(11, 12, 16-20) Notably, the material involved in this study, $\mathrm{Ag}_{0.48} \mathrm{VOPO}_{4} \cdot 1.9 \mathrm{H}_{2} \mathrm{O}$, has the highest practical energy density of the series, with a lower silver content and higher initial discharge voltage $\left(>3.6 \mathrm{~V}\right.$ vs. $\left.\mathrm{Li}^{\prime} / \mathrm{Li}^{+}\right) .(17)$ This material is also distinct in that $\mathrm{Ag}^{0}$ is not the predominant product of initial discharge. V K-edge and Ag K-edge XAS measurements in concert, affirmed that the initial reduction is $\mathrm{V}^{+5} \rightarrow \mathrm{V}^{+4}$ while the silver are reduced between 0.4 and 1.0 electron equivalents.(21) Further, $\mathrm{Ag}_{0.48} \mathrm{VOPO}_{4} \cdot 1.9 \mathrm{H}_{2} \mathrm{O}$ retains crystallinity during discharge and has shown the ability to be charged and cycled.(22)

Improving effective ionic and electronic conductivity is especially vital for high power batteries which require both rapid ion and electron transport. Synthetic control of the dimensions 
of cathode materials can have profound effects on their battery relevant electrochemistry where smaller crystallites have greater surface area and thus shorter diffusion pathways for ions, which can allow for more complete active material utilization.(22-25) Crystallite size control of $\mathrm{Ag}_{2} \mathrm{VO}_{2} \mathrm{PO}_{4}$ synthesized using a microwave synthesis technique has been studied and showed the material with smaller crystallites $(42 \mathrm{~nm})$ had larger ohmic resistances than the larger crystallite $(60 \mathrm{~nm})$ sized material, where the increase in ohmic resistance was attributed to a higher number of grain boundaries and consequently greater interparticle resistance in spite of the initial reduction reaction forming $\mathrm{Ag}^{0}$.(20)

This study reports synthesis parameters for the preparation of $\mathrm{Ag}_{0.50} \mathrm{VOPO}_{4} \cdot 1.9 \mathrm{H}_{2} \mathrm{O}$ with systematic control of crystallite and particle size. The series of materials was fully characterized

and explored to quantify the impact of crystallite size on the realized functional capacity and energy delivery, under intermittent pulsatile discharge and galvanostatic (dis)charge conditions. These results contribute to the understanding of the role of crystallite size on electrochemistry and towards deliberate targeted synthesis of other inorganic materials for energy storage.

\section{EXPERIMENTAL}

2.1. Material Synthesis and Characterization. $\mathrm{Ag}_{0.50} \mathrm{VOPO}_{4} \cdot \mathrm{H}_{2} \mathrm{O}$ was prepared using a stirred hydrothermal synthesis method based on modifications to a previously reported hydrothermal method.(17, 26) Stoichiometric amounts of silver powder (Alfa Aesar) and vanadium pentoxide (GFE Metalle und Materialien) powder were combined and added to an autoclave with 85 wt\% $\mathrm{H}_{3} \mathrm{PO}_{4}(\mathrm{BDH})$ and deionized water. Reactors were heated to 
temperatures from 25 to $120^{\circ} \mathrm{C}$ for 24 hours then cooled to room temperature. Products were recovered using vacuum filtration, rinsed with deionized water and dried in a vacuum oven.

Powder X-ray diffraction (XRD) was performed using beamline 28-ID-2 of the National Synchrotron Light Source II at Brookhaven National Laboratory with an x-ray wavelength of $0.01899 \mathrm{~nm}$. XRD patterns were analyzed using PeakFit version 4.12 to determine full-width at half-maximum (FWHM) for specific crystal planes. Crystallite sizes were calculated with the Scherrer equation and instrumental broadening was accounted for with a lanthanum hexaboride $\left(\mathrm{LaB}_{6}\right)$ standard.(27) Rietveld refinement was also conducted using software GSAS-II.(28) A Thermo Scientific iCAP 6000 series ICP spectrometer was used to determine elemental ratios of the prepared materials using inductively coupled plasma optical emission spectroscopy (ICPOES). Thermogravimetric analysis (TGA) was performed with a TA Instruments SDT Q600 from room temperature to $580{ }^{\circ} \mathrm{C}$ at a heating rate of $5{ }^{\circ} \mathrm{C} / \mathrm{min}$. Brunauer-Emmett-Teller (BET) surface area was measured using nitrogen gas adsorption with a Quantachrome Nova 4200e. Scanning electron microscope (SEM) images were obtained using a JEOL 6010Plus SEM with a tungsten filament. Particle size analysis was done using a Horiba Partica laser scattering particle size distribution analyzer LA-950V2.

2.2 Electrochemical Testing. Composite cathodes were formed with a mixture of $\mathrm{Ag}_{0.50} \mathrm{VOPO}_{4} \cdot \mathrm{H}_{2} \mathrm{O}$ (70\% by wt.), graphite ( $5 \%$ by wt.), carbon ( $20 \%$ by wt.), and polyvinyldiene fluoride (5\% by wt.). Electrode slurries were spread onto aluminum foil using N-methyl-2pyrrolidone. Coin type cells were constructed with composite cathodes, lithium metal anodes, and an electrolyte comprised of $1 \mathrm{M}$ lithium tetrafluoroborate $\left(\mathrm{LiBF}_{4}\right)$ dissolved in propylene carbonate/dimethyl carbonate (50/50 by volume). 
Coin cells were tested using a Maccor battery tester. Batteries used for constant current cycling were discharged and charged at $6.7 \mathrm{~mA}$ per gram of $\mathrm{Ag}_{0.50} \mathrm{VOPO}_{4} \cdot \mathrm{H}_{2} \mathrm{O}$ between 3.7 and 2.0 V vs. $\mathrm{Li} / \mathrm{Li}^{+}$. Pulse testing used a constant current of $1.7 \mathrm{~mA}$ per gram of active material with pulses of $33 \mathrm{~mA}$ per gram of active material every eight hours with a lower voltage limit of $1.5 \mathrm{~V}$ vs. $\mathrm{Li} / \mathrm{Li}^{+}$.

\section{RESULTS AND DISCUSSION}

3.1. Material Characterization. Powder XRD patterns for $\mathrm{Ag}_{0.50} \mathrm{VOPO}_{4} \cdot 1.9 \mathrm{H}_{2} \mathrm{O}$ synthesized at 25, 40, 60 80, 100 and $120{ }^{\circ} \mathrm{C}$ are shown in Figure 1, and results from Rietveld refinement are in Table 1. The crystal structure of $\mathrm{Ag}_{0.50} \mathrm{VOPO}_{4} \cdot 1.9 \mathrm{H}_{2} \mathrm{O}$ matches well with the reference pattern PDF \#97-016-2386 which belongs to the triclinic space group P $\overline{1}(26)$ and is shown in the inset of Figure 1. The crystal is comprised of layers of $\mathrm{VO}_{6}$ octahedra and $\mathrm{PO}_{4}$ tetrahedra with interlayer silver atoms and water molecules.

Decreases in the synthesis temperature result in XRD peaks that are broader and less intense,

Figure 1. Peak width was determined using fitting software to determine the full width at halfmaximum (FWHM) intensity and the Scherrer equation to determine the crystallite size of a plane based on an individual peak in an XRD pattern.(27) Crystallite sizes for the (012) and (013) planes for each synthesis temperature are given in Figure 1B represented by the peaks at 2-theta values of $2.22^{\circ}$ and $3.27^{\circ}$, respectively. These planes were chosen as they produced reflections with little or no convolution from other planes with similar diffraction angles. It should be noted that the Scherrer equation is more precise for crystallites $<100 \mathrm{~nm}$, but still usable for crystallites up to $200 \mathrm{~nm}$.(29) The data show that crystallite size generally increased with synthesis temperature, although the material synthesized at $100{ }^{\circ} \mathrm{C}$ deviated from this trend. 
Results from ICP-OES found the silver-to-vanadium ratio to be 0.49 for samples synthesized at 100 and $120^{\circ} \mathrm{C}$ while samples formed at $25,40,60$ and $80^{\circ} \mathrm{C}$ contained $\mathrm{Ag}: \mathrm{V}$ ratios of 0.50 . Results from thermogravimetric analysis (TGA) are presented in Figure 2. Notably, $\mathrm{Ag}_{0.50} \mathrm{VOPO}_{4} \cdot 1.9 \mathrm{H}_{2} \mathrm{O}$ contains water molecules as part of the crystal structure. Appreciable weight loss began to occur when the TGA temperature reached $\sim 80{ }^{\circ} \mathrm{C}$ and continued until 300 ${ }^{\circ} \mathrm{C}$ and is attributed to the loss of water from the crystal lattice. Figure $\mathbf{2 B}$ shows the weight loss percentage of samples from the samples prepared at each synthesis temperature. The larger sized $\mathrm{Ag}_{0.50} \mathrm{VOPO}_{4} \cdot 1.9 \mathrm{H}_{2} \mathrm{O}$ samples (higher synthesis temperature) show greater thermal stability.

Chemical formulas for materials synthesized at each temperature were similar, based on ICPOES and TGA determinations. The measured Ag contents (x) ranged from 0.49-0.50, and the measured water contents (n) ranged from 1.84-2.07 per $\mathrm{Ag}_{\mathrm{x}} \mathrm{VOPO}_{4} \cdot \mathrm{nH}_{2} \mathrm{O}$ formula unit, with no trend as a function of synthesis temperature.

SEM images of $\mathrm{Ag}_{0.50} \mathrm{VOPO}_{4} \cdot \mathrm{H}_{2} \mathrm{O}$ synthesized at the various temperatures are shown in Figure 3. All images were recorded at $10,000 \mathrm{x}$ in order to compare differences in particle morphology. $\mathrm{Ag}_{0.50} \mathrm{VOPO}_{4} \cdot \mathrm{H}_{2} \mathrm{O}$ develops large plate structures with two long dimensions and one short dimension. Comparison of the images shows that particle size generally increases with synthesis temperature. Samples synthesized at $25^{\circ} \mathrm{C}$ formed particles $\sim 1 \mu \mathrm{m}$ across while samples prepared at $120{ }^{\circ} \mathrm{C}$ formed plates with dimensions as large as 10 by $10 \mu \mathrm{m}$. The samples prepared between 40 and $100{ }^{\circ} \mathrm{C}$ yielded plate-like particles with intermediate dimensions. BET surface area of the product from each synthesis temperature was measured via nitrogen gas adsorption, Figure 4A. There was a trend where the samples synthesized at lower temperatures (smaller crystallite sizes) exhibited larger surface areas. 
Particle size of the materials determined by laser light scattering is shown in Figure 4B. The particle distributions of the 25 and $40{ }^{\circ} \mathrm{C}$ synthesis temperatures are unimodal reflecting that the three dimensions of their plate-like particles are similar in size. The 60, 80, 100 and $120{ }^{\circ} \mathrm{C}$ samples exhibited bimodal distributions where likely one peak represents laser diffraction from the thin edge and the other peak represents laser diffraction from the large faces of the plate-like particles.

\subsection{Electrochemistry.}

Two electrode cells with $\mathrm{Ag}_{0.50} \mathrm{VOPO}_{4} \cdot 1.9 \mathrm{H}_{2} \mathrm{O}$ as the active cathode material and $\mathrm{Li}$ metal as the anode material were discharged at a constant current of $6.7 \mathrm{~mA}$ per gram of active material. A plot of voltage versus first discharge capacity is displayed in Figure 5 showing both gravimetric capacity and molar electron equivalents. The voltage profile depicts an initial voltage plateau at $\sim 3.7 \mathrm{~V}$ vs. $\mathrm{Li} / \mathrm{Li}^{+}$followed by a long voltage plateau at $\sim 2.3 \mathrm{~V}$ vs. $\mathrm{Li} / \mathrm{Li}^{+}$and agrees with previously reported discharge curves for this material.(21) The reduction pathway can be described as shown below(1, 17):

$\mathrm{Ag}_{0.50} \mathrm{VOPO}_{4} \stackrel{\mathrm{xLi}(\mathrm{x} \leq 0.50)}{\longrightarrow} \mathrm{Li}_{\mathrm{x}} \mathrm{Ag}_{0.50} \mathrm{VOPO}_{4}$

$\mathrm{Li}_{\mathrm{x}} \mathrm{Ag}_{0.50} \mathrm{VOPO}_{4} \stackrel{\mathrm{yLI}(\mathrm{y} \leq 0.50)}{\longrightarrow} \mathrm{Li}_{0.50+\mathrm{y}} \mathrm{Ag}_{0.50-\mathrm{y}} \mathrm{VOPO}_{4}+\mathrm{yAg}^{0}$

$\mathrm{Li}_{0.50+\mathrm{y}} \mathrm{Ag}_{0.50-\mathrm{y}} \mathrm{VOPO}_{4}+\mathrm{yAg}^{0} \stackrel{\mathrm{zLi}(\mathrm{z} \leq 0.50)}{\longrightarrow} \mathrm{Li}_{1.00+\mathrm{z}} \mathrm{VOPO}_{4}+0.50 \mathrm{Ag}^{0}$

The first lithiation step reduces $\mathrm{V}^{5+}$ to $\mathrm{V}^{4+}$, which is associated with the initial voltage plateau 3.7 volts then $\mathrm{Ag}^{+}$reduction-displacement begins to occur concurrently with vanadium reduction at 0.37 electrons when the voltage drops to $\sim 2.3 \mathrm{~V}$ vs. $\mathrm{Li} / \mathrm{Li}^{+}$. Smaller sized materials formed at lower temperatures $\left(40\right.$ and $60{ }^{\circ} \mathrm{C}$ ) yielded higher capacity to $2.0 \mathrm{~V} \mathrm{vs}$. $\mathrm{Li} / \mathrm{Li}^{+}$than 
those formed at higher temperature (100 and $\left.120^{\circ} \mathrm{C}\right)$. However, the smallest material synthesized at $25^{\circ} \mathrm{C}$ showed an abbreviated voltage plateau at $3.7 \mathrm{~V}$ vs. $\mathrm{Li} / \mathrm{Li}^{+}$compared to the other materials. This suggests that crystallite size reduction and generation of materials with small crystallites can deliver higher capacity, but there is a limit at which downsizing active material becomes detrimental to performance. For this material the smallest crystallites (11 nm) are less effective (less capacity) than the next smallest crystallites (22 nm) which provided the most capacity of all tested crystallite sizes.

To further study the crystallite size effect, a series of cells were discharged at different rates, Figure 6. The larger sized materials (prepared at 60, 100, and $120{ }^{\circ} \mathrm{C}$ ) displayed similar first voltage plateaus under different rates of discharge. However, the material synthesized at $25{ }^{\circ} \mathrm{C}$ delivered significantly less capacity at the $\sim 3.7 \mathrm{~V}$ vs. $\mathrm{Li}^{\prime} / \mathrm{Li}^{+}$plateau at high rates of discharge. Smaller crystallites have more grain boundaries which can increase interfacial resistance.(20) Thus, the lack of the initial $\sim 3.7 \mathrm{~V}$ vs. $\mathrm{Li} / \mathrm{Li}^{+}$plateau for the $25{ }^{\circ} \mathrm{C}$ sample under high rate is likely caused by a combination of surface disorder at the surface of the crystal and a larger ohmic resistance due to grain boundaries.

In order to probe the DC resistance of $\mathrm{Ag}_{0.50} \mathrm{VOPO}_{4} \cdot 1.9 \mathrm{H}_{2} \mathrm{O}$, a pulse discharge test was used where high-current (33 mA/g) pulses were applied every 8 hours during constant current (1.7 mA/g) discharge with a $1.5 \mathrm{~V}$ vs. $\mathrm{Li} / \mathrm{Li}^{+}$lower voltage limit, Figure 7. In general, the materials synthesized at lower temperatures $\left(40\right.$ and $60{ }^{\circ} \mathrm{C}$ ) delivered greater capacity to $1.5 \mathrm{~V} \mathrm{vs.} \mathrm{Li} / \mathrm{Li}^{+}$ than those formed at higher temperatures $\left(100\right.$ and $\left.120{ }^{\circ} \mathrm{C}\right)$. The material synthesized at $40{ }^{\circ} \mathrm{C}$ could be reduced by 2.95 electron equivalents while the material synthesized at $120^{\circ} \mathrm{C}$ by only 2.20 electron equivalents, $\sim 25 \%$ less delivered capacity. The smallest crystallite sized material $\left(25{ }^{\circ} \mathrm{C}\right.$ ) showed no $3.7 \mathrm{~V}$ vs. $\mathrm{Li} / \mathrm{Li}^{+}$plateau and delivered the lowest capacity. Thus, smaller 
crystallite and particle sizes can contribute to a more complete utilization of the $\mathrm{Ag}_{0.50} \mathrm{VOPO}_{4} \cdot 1.9 \mathrm{H}_{2} \mathrm{O}$ active material by allowing for more facile ion transport under these test conditions but there is a limit at which decreasing active material size will be detrimental to performance. Designing the morphology of active material requires balancing the slow diffusion rates of lithium and silver ions through larger crystals and the greater interfacial resistances associated with increased grain boundaries from smaller crystals.

Analysis of the pulse testing data quantified the resistance of the batteries during discharge. The inset of Figure 7 shows the voltage profile of a five second pulse. The initial rapid voltage drop within the first few milliseconds was attributed to internal cell resistance, identified as ohmic resistance $\left(\mathrm{R}_{\mathrm{ohm}}\right)$. The voltage drop from the continued five second pulse was attributed to polarization in the cell $\left(\mathrm{R}_{\mathrm{pol}}\right)$. Ohmic and polarization resistances were calculated using Ohm's law with voltage drop and applied current. Ohmic resistance is influenced by electrode geometry, thickness and active material contacts while polarization resistance relates to concentration gradients and the diffusion of ions during discharge.(30)

Ohmic and polarization resistances were calculated for pulses at the start of discharge (0 electron equivalents), 0.14 electrons, 0.28 electrons, 0.4 electrons, and 1.0 electrons. These points were chosen to show the evolution of ohmic and polarization resistance as discharge progressed from the $3.7 \mathrm{~V}$ vs. $\mathrm{Li} / \mathrm{Li}^{+}$plateau through the $2.3 \mathrm{~V}$ vs. $\mathrm{Li} / \mathrm{Li}^{+}$plateau and are plotted against synthesis temperature in Figure 8. Two data points were measured for each synthesis temperature to affirm repeatability. Ohmic resistance decreased with increasing synthesis temperature for all discharge levels. This trend suggests that more grain boundaries increases interfacial contacts subsequently increasing ohmic resistance. Also, lower resistance for the larger crystal samples implies that conduction within a crystal is more facile than across grain 
boundaries. With carbon present in the electrode, the formation of silver nanoparticles during discharge beyond the first plateau does not appear to significantly impact the ohmic resistance. The more intriguing observations are the polarization trends with depth of discharge (DOD). The smallest crystallite size, prepared at $25{ }^{\circ} \mathrm{C}$, had a distinctive discharge curve with a short plateau at $3.7 \mathrm{~V}$ vs. $\mathrm{Li}^{-\mathrm{Li}^{+}}$so those data points are distinct from the general trend. Polarization resistance of the other samples increases with crystallite size at the start of discharge and at 0.14 electrons DOD. This can be rationalized in considering that the larger crystallite sizes have longer bulk diffusion pathways for $\mathrm{Li}^{+}$ions and lower surface area. However, once the electrodes reach the $2.3 \mathrm{~V}$ vs. $\mathrm{Li} / \mathrm{Li}^{+}$plateau where silver metal nanoparticles have formed, the trend is inverted and the polarization resistance decreases with increasing crystallite size. The smaller crystallite sizes undergo a greater increase in polarization resistance during discharge. For example, the samples synthesized at $40{ }^{\circ} \mathrm{C}$ had an average polarization resistance of 116 ohms at 0.14 electrons DOD and then 720 ohms at 1.0 electrons DOD. Meanwhile the samples synthesized at $120^{\circ} \mathrm{C}$ had average polarization resistances of 283 ohms initially and 522 ohms at 1.0 electron DOD. At 0.37 electrons DOD $\mathrm{Ag}^{+}$undergoes a reduction displacement reaction to form $\mathrm{Ag}^{0}$ on the particle surface. Silver nanoparticles can form on $\mathrm{Ag}_{0.50} \mathrm{VOPO}_{4} \cdot 1.9 \mathrm{H}_{2} \mathrm{O}$ particle surfaces and in grain boundaries between crystallites upon reduction. More surface $\mathrm{Ag}^{0}$ formation on the surfaces and grain boundaries for the smaller crystallites may contribute to increased polarization.

The cells from the galvanostatic reduction, Figure 5, were charged to test the electrochemical reversibility of $\mathrm{Ag}_{0.50} \mathrm{VOPO}_{4} \cdot 1.9 \mathrm{H}_{2} \mathrm{O}$ synthesized at different temperatures. Voltage profiles of the first charge to $3.7 \mathrm{~V}$ vs. $\mathrm{Li} / \mathrm{Li}^{+}$and second discharge to $2.0 \mathrm{~V}$ vs. $\mathrm{Li} / \mathrm{Li}^{+}$are exhibited in Figure 9. The smaller sized materials reached higher voltages earlier during the charge process 
indicative of higher polarization consistent with the results from pulse testing. The larger-sized materials delivered more capacity upon their second discharge. This may be due to larger sized materials having more $\mathrm{Ag}^{+}$reduction sites that were inactive in the first discharge and became accessible in the second discharge.

First and second discharge capacities of these materials were far superior to previous reports of this material. Previous studies achieved 0.72 electrons on first discharge to $2.0 \mathrm{~V} \mathrm{vs.} \mathrm{Li}^{-} \mathrm{Li}^{+}$and 0.20 electron equivalents during second discharge.(22) Results reported here achieved up to 1.7 electrons on first discharge to $2.0 \mathrm{~V}$ vs $\mathrm{Li} / \mathrm{Li}^{+}$and between 0.7 and 0.9 electrons during second discharge. The previous report used a hydrothermal synthesis at $180{ }^{\circ} \mathrm{C}$ that produced crystallite sizes exceeding the limitations of the Scherrer equation (over $200 \mathrm{~nm}$ ) which are much larger than the samples reported here (11-120 nm). Comparison with previous reports highlights the benefits of synthetically controlling active material physiochemical properties as materials with smaller crystallite and particle size delivered more than double the previously reported capacity for $\mathrm{Ag}_{0.50} \mathrm{VOPO}_{4} \cdot 1.9 \mathrm{H}_{2} \mathrm{O}$.

Electrochemical tests have shown that materials with smaller crystallite and particle size deliver higher capacity on first discharge. The materials synthesized in this report delivered greater capacity during first and second discharge than had been previously reported for $\mathrm{Ag}_{0.50} \mathrm{VOPO}_{4} \cdot 1.9 \mathrm{H}_{2} \mathrm{O}$. Greater capacities are likely attributed to smaller crystallite and particle sizes which reduce diffusion pathways and provide facile ion access. Pulse testing showed that ohmic resistance decreases with increasing cathode active material crystallite size. Polarization resistance increased during discharge for all crystallite sizes but smaller materials underwent relatively greater escalations (116 to 720 ohms for 22nm crystallites) than larger crystallites (283 
to 522 ohms for $120 \mathrm{~nm}$ crystallites). Discrepancies in changes to polarization resistance are attributed to $\mathrm{Ag}^{0}$ formation at the surfaces and grain boundaries of active material crystallites.

\section{SUMMARY}

A stirred hydrothermal method was used to synthesize $\mathrm{Ag}_{0.50} \mathrm{VOPO}_{4} \cdot 1.9 \mathrm{H}_{2} \mathrm{O}$ where crystallite size was controlled by varying synthesis temperature between 25 and $120^{\circ} \mathrm{C}$ to yield materials with sizes of 11, 22, 38, 40, 49 and $120 \mathrm{~nm}$. The phase structure and composition of the materials were similar over the range of synthesis temperatures. Notably, the morphology of the samples became more plate-like with increasing synthesis temperature where the samples prepared at low temperature displayed a more granular morphology. The surface area was inversely related to crystallite size where the smallest crystallite size material had a surface area $\left(8.8 \mathrm{~m}^{2} / \mathrm{g}\right) \sim 8$ fold higher than the largest sample $\left(1.2 \mathrm{~m}^{2} / \mathrm{g}\right)$.

The electrochemistry of the series of materials was probed in a lithium battery environment. The $\mathrm{Ag}_{0.50} \mathrm{VOPO}_{4} \cdot 1.9 \mathrm{H}_{2} \mathrm{O}$ samples with $22 \mathrm{~nm}$ crystallites delivered $\sim 25 \%$ more first discharge capacity than the samples with larger $120 \mathrm{~nm}$ crystallites. Notably, the samples synthesized in this report via the stirred reactor approach delivered more than double the capacity previously reported for this material. Cell resistance was analyzed through the careful examination of electrochemical discharge data collected under a pulsatile method. The ohmic resistance decreased with increasing crystallite size indicating that intracrystal conduction may be more facile than conduction across grain boundaries. Polarization resistance increased to a greater extent during discharge for materials with smaller crystallites (600 ohm increase for $22 \mathrm{~nm}$ crystallites) than larger crystallites (240 ohm increase for $120 \mathrm{~nm}$ crystallites). This study 
demonstrated a synthetic method that enabled systematic control of crystallite size of a polyanionic material enabling study of crystallite size on the resultant electrochemistry. Interparticle and intraparticle conduction are both important. Thus, careful control crystallite size is demonstrated as an approach that enables tuning of materials properties for specific energy storage applications.

\section{ASSOCIATED CONTENT}

\section{Supporting Information}

\section{AUTHOR INFORMATION}

\section{Corresponding Authors}

*E-mail: amy.marschilok@stonybrook.edu

*E-mail: esther.takeuchi@stonybrook.edu

*E-mail: kenneth.takeuchi.1@stonybrook.edu

\section{Author Contributions}

The manuscript was written through contributions of all authors. All authors have given approval to the final version of the manuscript.

\section{ACKNOWLEDGEMENT}

The authors acknowledge the Center for Mesoscale Transport Properties, an Energy Frontier Research Center supported by the U.S. Department of Energy, Office of Science, Basic Energy Sciences, under Award \#DE-SC0012673 for financial support. Use of the National Synchrotron 
Light Source II, Brookhaven National Laboratory, was supported by the U.S. Department of Energy, Office of Science, Office of Basic Energy Sciences, under Contract No. DE-SC0012704.

The authors express their appreciation to Eric Dooryhee for assistance with the measurements at XPD beamline. M.M.H. acknowledges that this material is based upon work supported by the National Science Foundation Graduate Research Fellowship Program under Grant No. 1109408.

\section{REFERENCES}

1. D. C. Bock, A. C. Marschilok, K. J. Takeuchi and E. S. Takeuchi, Electrochim. Acta, 84, 155 (2012).

2. K. J. Takeuchi, A. C. Marschilok, S. M. Davis, R. A. Leising and E. S. Takeuchi, Coord. Chem. Rev., 219-221, 283 (2001).

3. R. A. Leising, W. C. Thiebolt and E. S. Takeuchi, Inorganic Chemistry, 33, 5733 (1994).

4. $\quad$ F. Sauvage, V. Bodenez, H. Vezin, T. A. Albrecht, J.-M. Tarascon and K. R. Poeppelmeier, Inorganic Chemistry, 47, 8464 (2008).

5. Y. Zhang, K. C. Kirshenbaum, A. C. Marschilok, E. S. Takeuchi and K. J. Takeuchi, Chemistry of Materials, 28, 7619 (2016).

6. F. Sauvage, V. Bodenez, J. M. Tarascon and K. R. Poeppelmeier, Inorganic Chemistry, 49, 6461 (2010).

7. J. L. Durham, K. Kirshenbaum, E. S. Takeuchi, A. C. Marschilok and K. J. Takeuchi, Chem. Commun. (Cambridge, U. K.), 51, 5120 (2015).

8. K. E. Farley, A. C. Marschilok, E. S. Takeuchi and K. J. Takeuchi, Electrochem. SolidState Lett., 15, A23 (2012).

9. C. J. Patridge, C. Jaye, H. Zhang, A. C. Marschilok, D. A. Fischer, E. S. Takeuchi and S. Banerjee, Inorg. Chem., 48, 3145 (2009). 
10. M. Morcrette, P. Rozier, L. Dupont, E. Mugnier, L. Sannier, J. Galy and J. M. Tarascon, Nat. Mater., 2, 755 (2003).

11. A. C. Marschilok, K. J. Takeuchi and E. S. Takeuchi, Electrochem. Solid-State Lett., 12, A5 (2008).

12. E. S. Takeuchi, A. C. Marschilok, K. Tanzil, E. S. Kozarsky, S. Zhu and K. J. Takeuchi, Chem. Mater., 21, 4934 (2009).

13. R. Zhang, T. A. Abtew, N. F. Quackenbush, L. W. Wangoh, M. Huie, A. B. Brady, D. Bock, H. Efstathiadis, M. S. Whittingham, A. C. Marschilok, K. J. Takeuchi, E. S. Takeuchi, P. Zhang and L. F. J. Piper, Chem. Mater., 28, 3428 (2016).

14. M. M. Huie, D. C. Bock, Z. Zhong, A. M. Bruck, J. Yin, E. S. Takeuchi, K. J. Takeuchi and A. C. Marschilok, Journal of The Electrochemical Society, 164, A6007 (2017).

15. K. Kirshenbaum, D. C. Bock, C.-Y. Lee, Z. Zhong, K. J. Takeuchi, A. C. Marschilok and E. S. Takeuchi, Science, 347, 149 (2015).

16. E. S. Takeuchi, C.-Y. Lee, P.-J. Cheng, M. C. Menard, A. C. Marschilok and K. J. Takeuchi, J. Solid State Chem., 200, 232 (2013).

17. Y. J. Kim, A. C. Marschilok, K. J. Takeuchi and E. S. Takeuchi, Journal of Power Sources, 196, 6781 (2011).

18. Y. J. Kim, K. J. Takeuchi, A. C. Marschilok and E. S. Takeuchi, J. Electrochem. Soc., 160, A2207 (2013).

19. A. C. Marschilok, E. S. Kozarsky, K. Tanzil, S. Zhu, K. J. Takeuchi and E. S. Takeuchi, J. Power Sources, 195, 6839 (2010).

20. J. Huang, A. C. Marschilok, E. S. Takeuchi and K. J. Takeuchi, Chem. Mater., 28, 2191 (2016).

21. K. C. Kirshenbaum, M. C. Menard, Y. J. Kim, A. C. Marschilok, K. J. Takeuchi and E. S. Takeuchi, Journal of The Electrochemical Society, 162, A1537 (2015). 
22. A. C. Marschilok, Y. J. Kim, K. J. Takeuchi and E. S. Takeuchi, J. Electrochem. Soc., 159, A1690 (2012).

23. A. Abraham, L. M. Housel, C. N. Lininger, D. C. Bock, J. Jou, F. Wang, A. C. West, A. C. Marschilok, K. J. Takeuchi and E. S. Takeuchi, ACS Cent. Sci., 2, 380 (2016).

24. L. Wu, F. Xu, Y. Zhu, A. B. Brady, J. Huang, J. L. Durham, E. Dooryhee, A. C. Marschilok, E. S. Takeuchi and K. J. Takeuchi, ACS Nano, 9, 8430 (2015).

25. S. Zhu, A. C. Marschilok, C.-Y. Lee, E. S. Takeuchi and K. J. Takeuchi, Electrochem. Solid-State Lett., 13, A98 (2010).

26. P. Ayyappan, A. Ramanan and C. C. Torardi, Inorg. Chem., 37, 3628 (1998).

27. P. Scherrer, Nachr. Ges. Wiss. Gottingen, 26, 96 (1918).

28. B. H. Toby and R. B. Von Dreele, J. Appl. Crystallogr., 46, 544 (2013).

29. U. Holzwarth and N. Gibson, Nat. Nanotechnol., 6, 534 (2011).

30. H.-G. Schweiger, O. Obeidi, O. Komesker, A. Raschke, M. Schiemann, C. Zehner, M. Gehnen, M. Keller and P. Birke, Sensors, 10, 5604 (2010). 


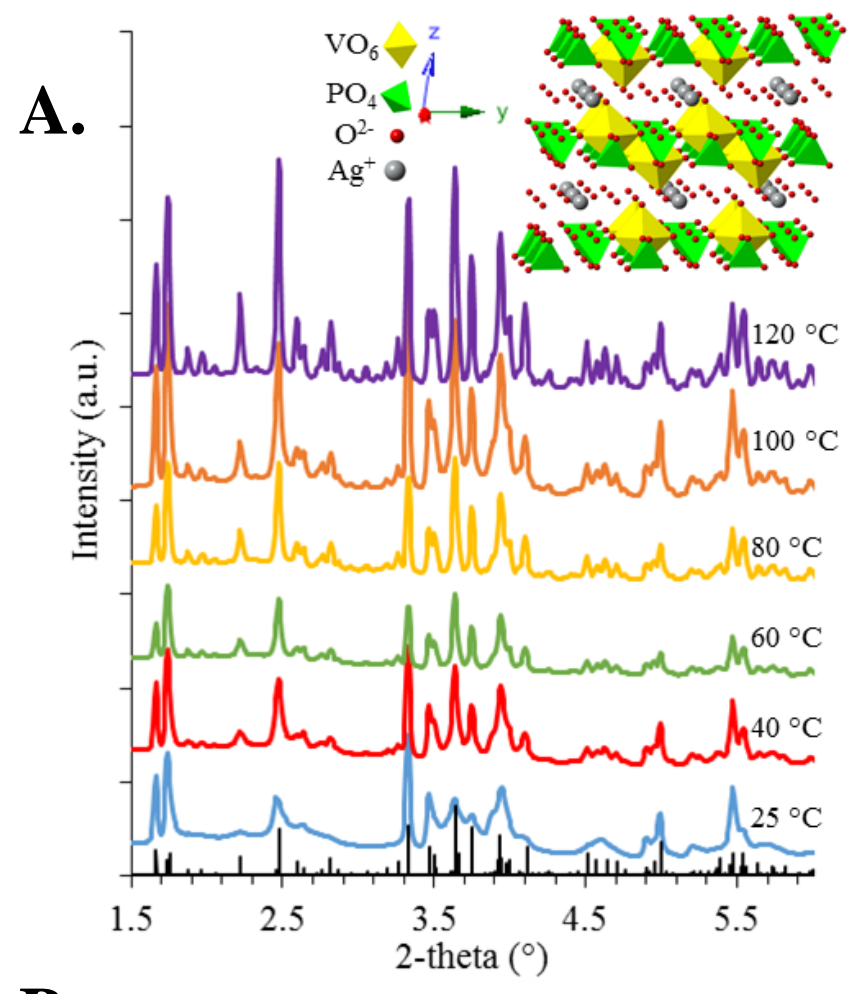

B.

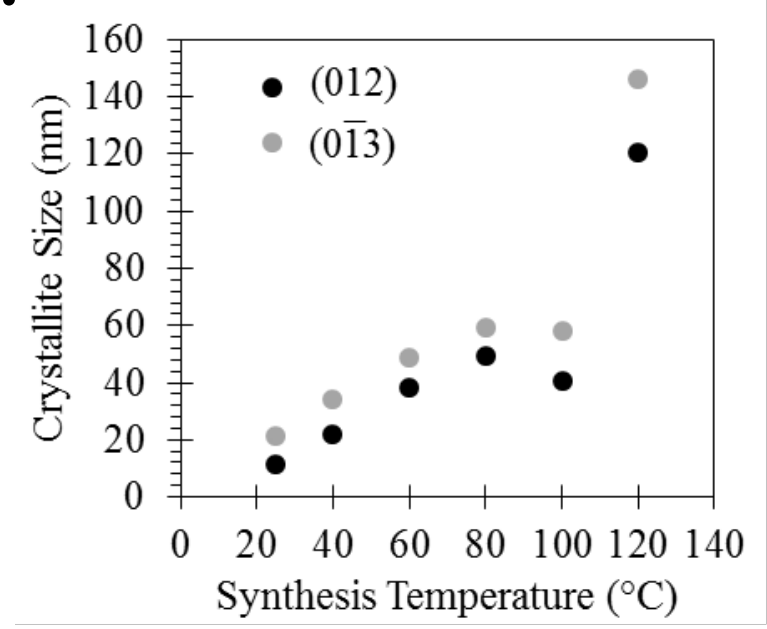

Figure 1. A) Synchrotron X-ray Diffraction (XRD) patterns of $\mathrm{Ag}_{0.50} \mathrm{VOPO}_{4} \cdot 1.9 \mathrm{H}_{2} \mathrm{O}$ synthesized at $25,40,60,80,100$ and $120^{\circ} \mathrm{C}$. Full pattern spectrum from 1.5 to $6.0^{\circ}$ 2-Theta. Reference PDF \#97-016-2386 also plotted as black lines at bottom of figure. Inset shows crystal structure of $\mathrm{Ag}_{0.50} \mathrm{VOPO}_{4} \cdot 1.9 \mathrm{H}_{2} \mathrm{O}$ represented by layers of $\mathrm{VO}_{6}$ octahedra, $\mathrm{PO}_{4}$ tetrahedra and interlayer Ag and $\mathrm{O}$ atoms. B) Crystallite sizes determined by Scherrer equation of various peaks in X-ray Diffraction (XRD) pattern and compared to synthesis temperature. 

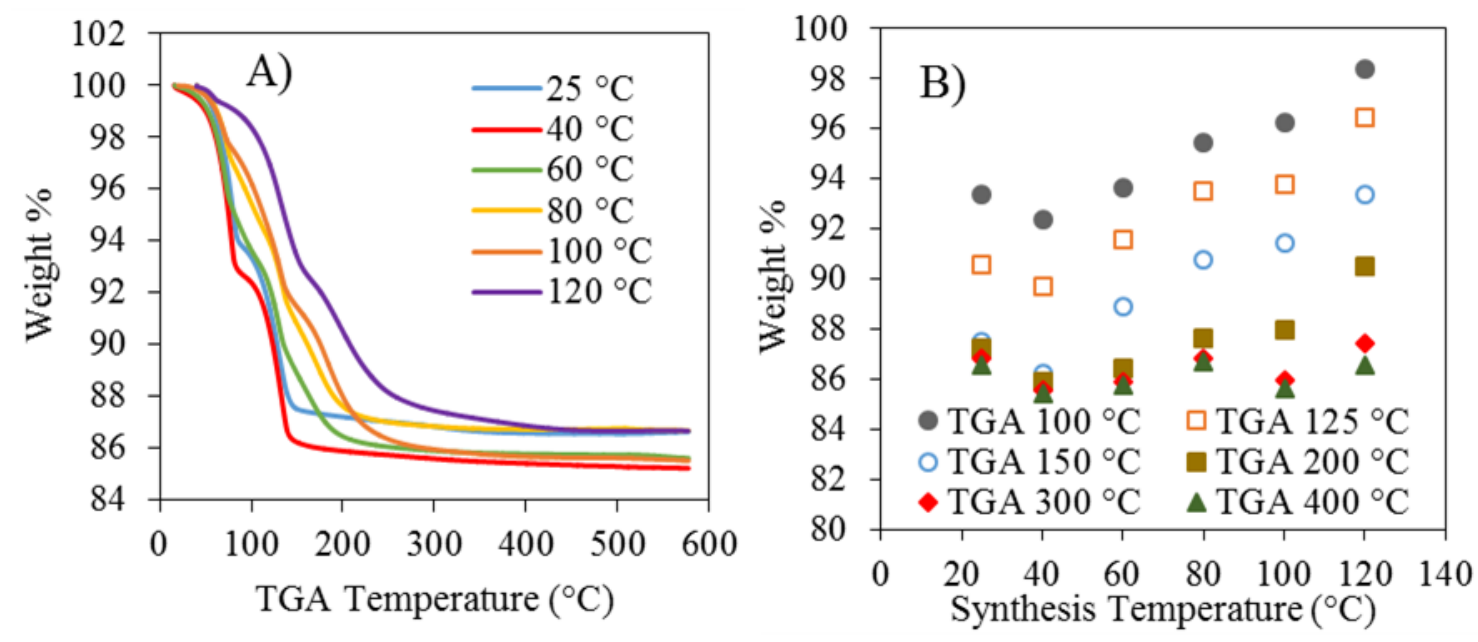

Figure 2. A) Thermogravimetric analysis (TGA) plots of $\mathrm{Ag}_{0.50} \mathrm{VOPO}_{4} \cdot 1.9 \mathrm{H}_{2} \mathrm{O}$ synthesized at 25, 40, 60 80, 100 and $120^{\circ} \mathrm{C}$. B) Selected temperature points 100, 125, 150, 200, 300 and 400 ${ }^{\circ} \mathrm{C}$ from TGA data.

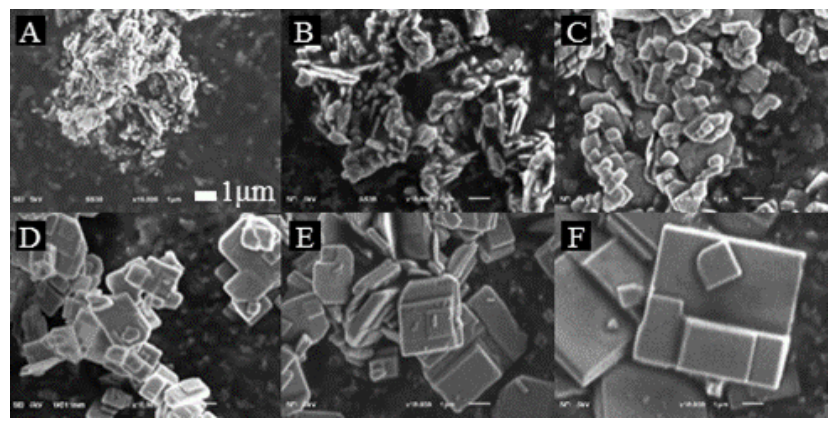

Figure 3. Scanning Electron Microscope (SEM) images at 10,000x of $\mathrm{Ag}_{0.50} \mathrm{VOPO}_{4} \cdot 1.9 \mathrm{H}_{2} \mathrm{O}$ synthesized at A) $25^{\circ} \mathrm{C}$, B) $\left.40^{\circ} \mathrm{C}, \mathrm{C}\right) 60^{\circ} \mathrm{C}$, D) $80^{\circ} \mathrm{C}$, E) $100{ }^{\circ} \mathrm{C}$, and F) $120^{\circ} \mathrm{C} . \quad 1$ micron scale bar shown in A) applies to all images. 

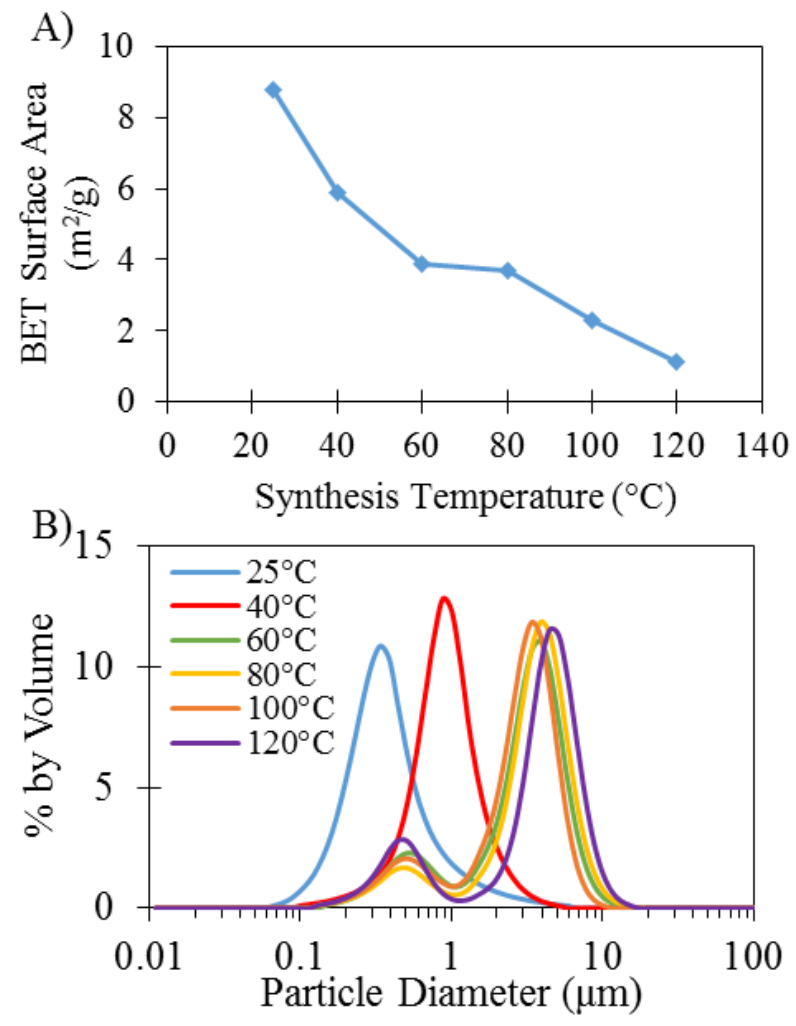

Figure 4. A) Brunauer-Emmett-Teller (BET) surface area measurements and B) particle size distribution determined by laser light scattering of $\mathrm{Ag}_{0.50} \mathrm{VOPO}_{4} \cdot 1.9 \mathrm{H}_{2} \mathrm{O}$ synthesized at 25, 40, 60 80, 100 and $120^{\circ} \mathrm{C}$. 


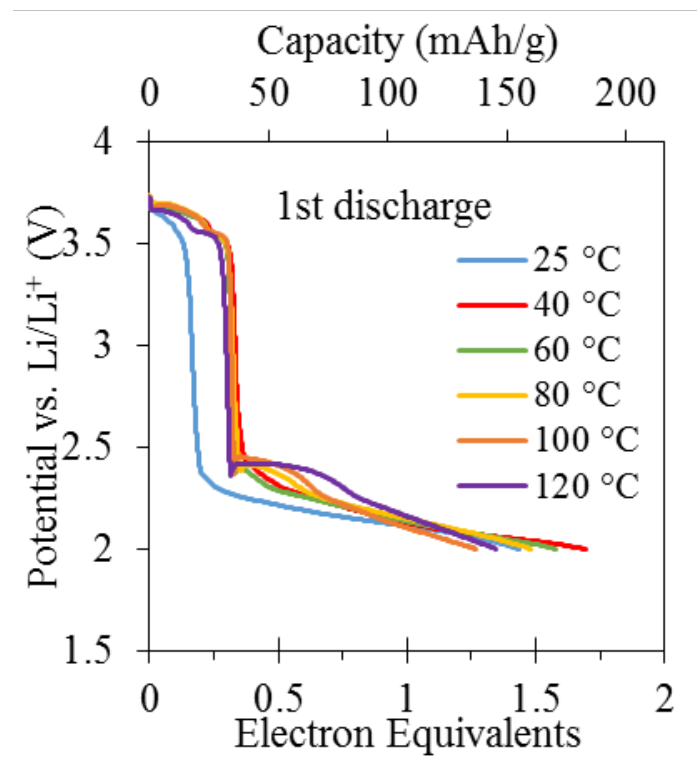

Figure 5. Voltage profiles during the first constant discharge of cells to $2.0 \mathrm{~V}$ vs. $\mathrm{Li} / \mathrm{Li}^{+}$tested at $6.7 \mathrm{~mA} / \mathrm{g}$.
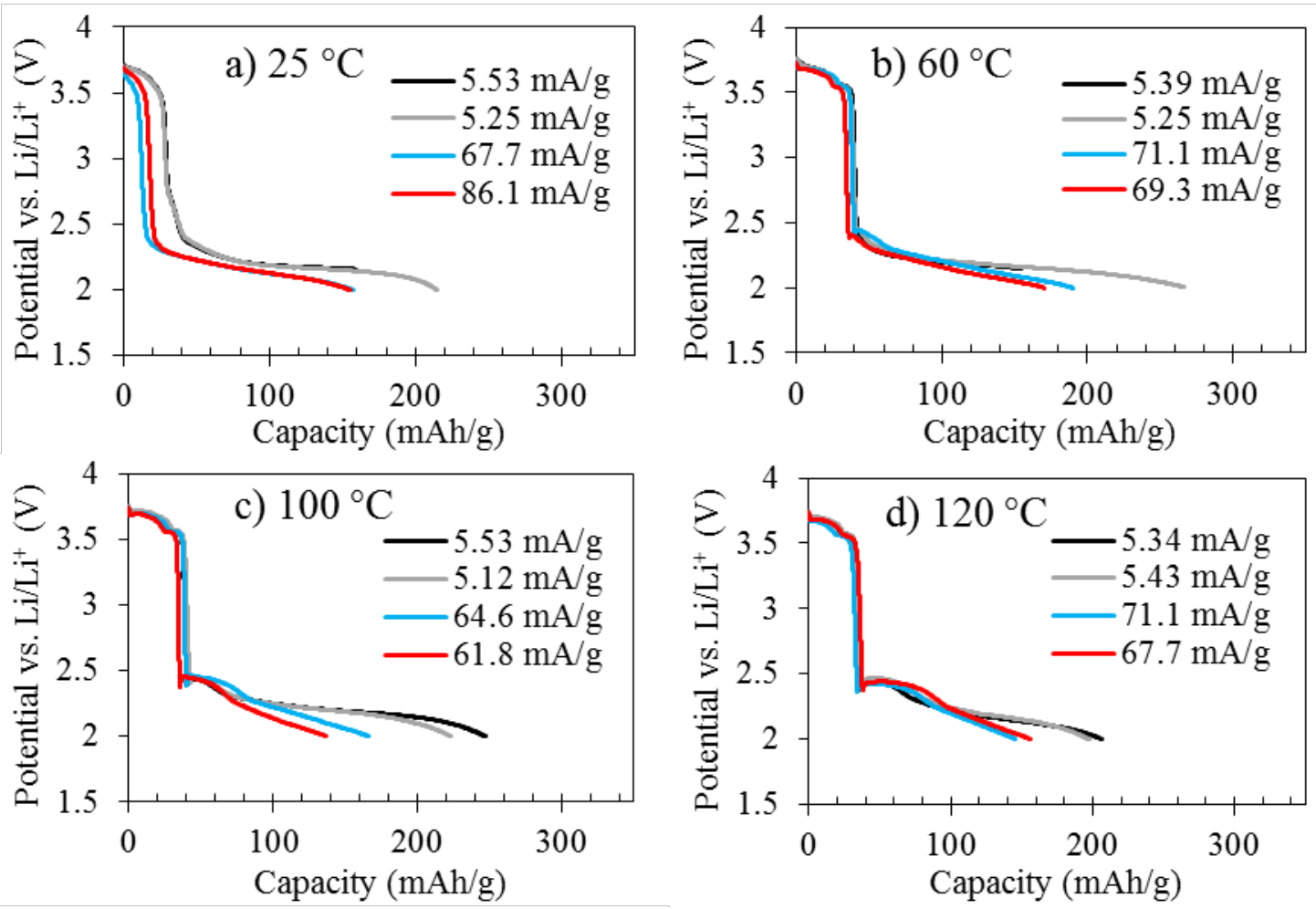

Figure 6. Constant current discharge curves of $\mathrm{Ag}_{0.50} \mathrm{VOPO}_{4} \cdot 1.9 \mathrm{H}_{2} \mathrm{O}$ synthesized at a)25, b) 60, c) 100 and d) $120^{\circ} \mathrm{C}$. Discharge current densities are labeled in the legend. 


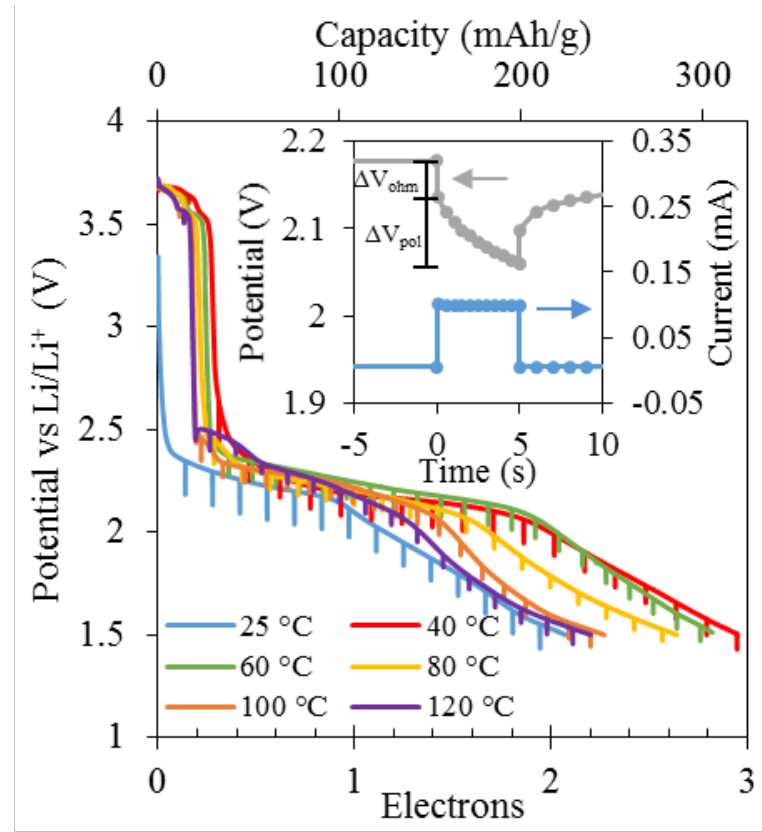

Figure 7. Pulse discharge curves for samples synthesized at various temperatures. Discharge current of $1.7 \mathrm{~mA} / \mathrm{g}$ active material with intermittent five-second pulses of $33 \mathrm{~mA} / \mathrm{g}$. Inset depicts typical discharge pulse of a cathode with material prepared at $40{ }^{\circ} \mathrm{C}$ at $\sim 1.0$ electron equivalent of reduction. $\Delta \mathrm{V}_{\text {ohm }}$ and $\Delta \mathrm{V}_{\text {polarization }}$ are shown as illustrative representations. 


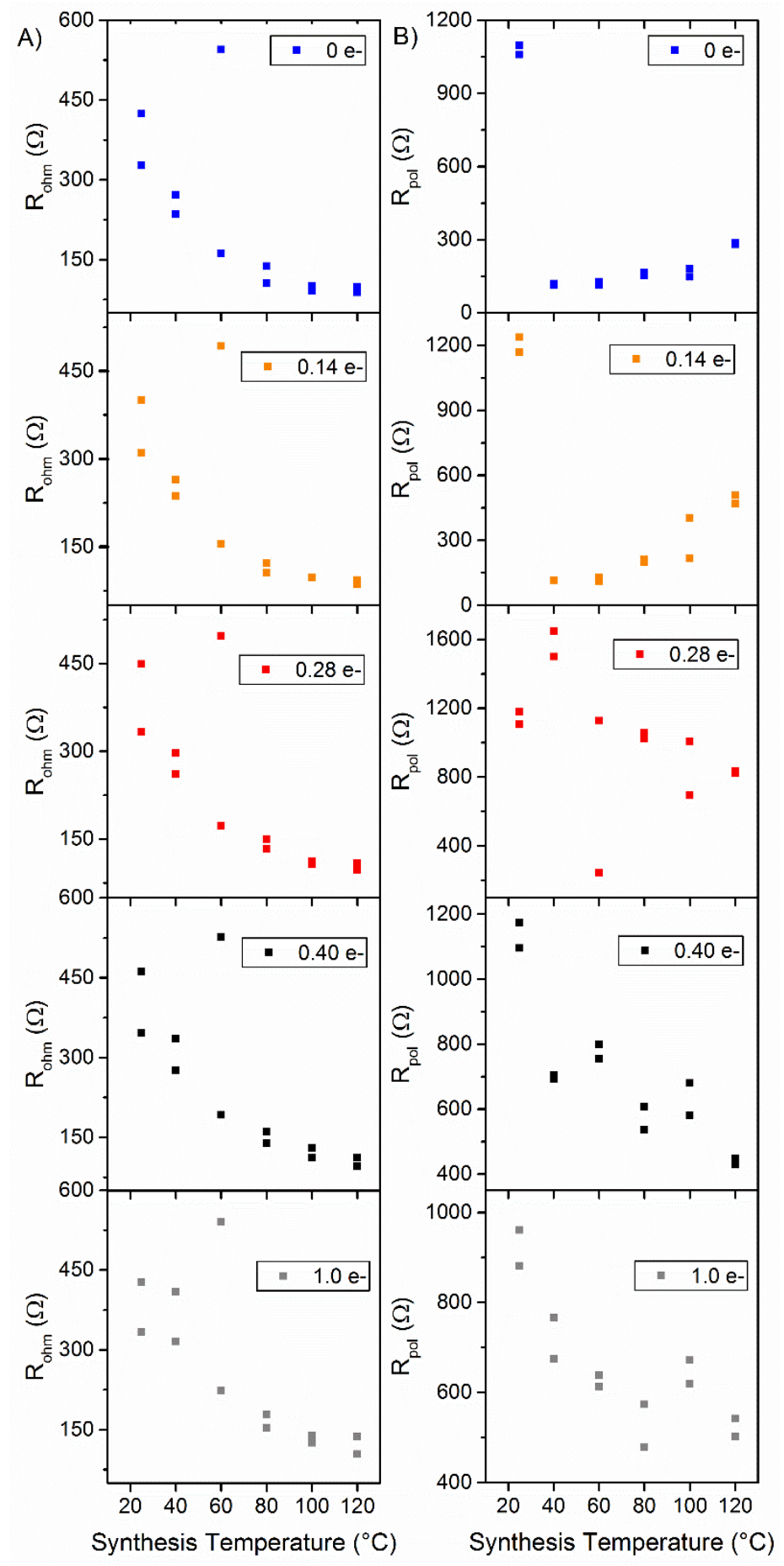

Figure 8. Cell resistance, in ohms, determined from pulse testing. Values were calculated at 0 , $0.14,0.28,0.4$, and 1.0 electron equivalents. Figures in A) represent the ohmic resistance and figures B) show polarization contributions to cell resistance. 


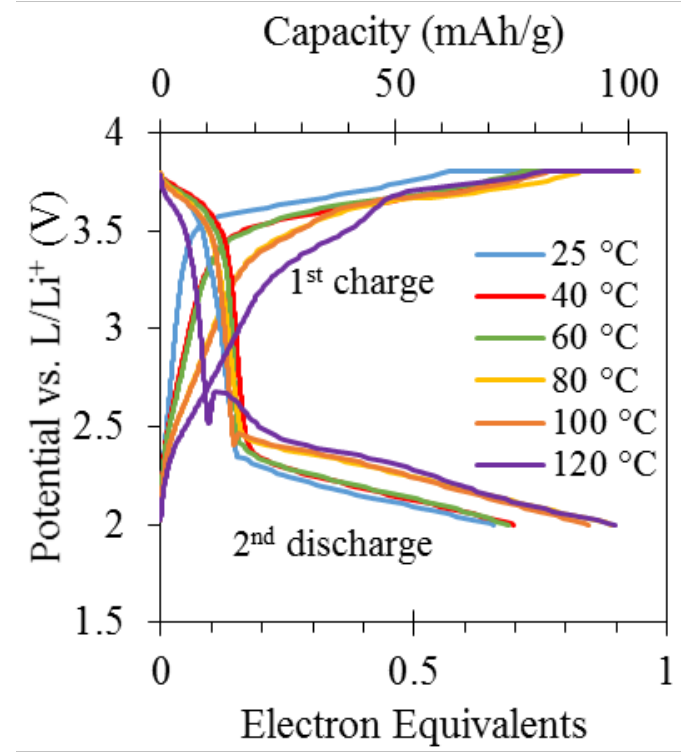

Figure 9. Voltage profiles during the first constant current charge and second discharge of cells tested at $6.7 \mathrm{~mA} / \mathrm{g}$ between 3.7 and $2.0 \mathrm{~V}$ vs. $\mathrm{Li} / \mathrm{Li}^{+}$. 
Table 1: Rietveld refinement results of powder x-ray diffraction of $\mathrm{Ag}_{0.50} \mathrm{VOPO}_{4} \cdot 1.9 \mathrm{H}_{2} \mathrm{O}$ formed at synthesis temperatures of $25,40,60,80,100$ and $120^{\circ} \mathrm{C}$. A uniaxial model was used with isotropic microstrain. Refinement was performed with a 15 term background function.

\begin{tabular}{|c|c|c|c|c|c|c|c|}
\hline \multirow[b]{2}{*}{ Atom } & \multirow[b]{2}{*}{ Position } & \multicolumn{6}{|c|}{ Synthesis Temperature $\left({ }^{\circ} \mathrm{C}\right)$} \\
\hline & & 25 & 40 & 60 & 80 & 100 & 120 \\
\hline \multirow{4}{*}{ Ag } & $\mathrm{x}$ & $0.568(2)$ & $0.575(1)$ & $0.5744(7)$ & $0.5741(6)$ & $0.576(1)$ & $0.5737(4)$ \\
\hline & $\mathrm{y}$ & $0.960(2)$ & $0.967(1)$ & $0.9701(9)$ & $0.9712(7)$ & $0.971(1)$ & $0.9710(4)$ \\
\hline & $\mathrm{z}$ & $0.249(1)$ & $0.2508(7)$ & $0.2517(5)$ & $0.2517(3)$ & $0.2506(5)$ & $0.2517(2)$ \\
\hline & $\begin{array}{c}\text { Frac. } \\
\text { Occupancy }\end{array}$ & $1.06(1)$ & $1.03(1)$ & $1.041(7)$ & $1.037(5)$ & $1.031(8)$ & $1.068(3)$ \\
\hline \multirow{3}{*}{ V1 } & $\mathrm{x}$ & $0.773(3)$ & $0.768(2)$ & $0.764(1)$ & $0.765(1)$ & $0.766(2)$ & $0.7641(7)$ \\
\hline & $\mathrm{y}$ & $0.265(4)$ & $0.255(2)$ & $0.2585(7)$ & $0.259(1)$ & $0.258(2)$ & $0.2606(7)$ \\
\hline & $\mathrm{z}$ & $0.460(2)$ & $0.459(1)$ & $0.4578(8)$ & $0.4560(5)$ & $0.458(1)$ & $0.4540(3)$ \\
\hline \multirow{3}{*}{ V2 } & $\mathrm{x}$ & $0.230(4)$ & $0.233(2)$ & $0.236(1)$ & $0.238(1)$ & $0.234(2)$ & $0.2378(7)$ \\
\hline & $\mathrm{y}$ & $0.228(3)$ & $0.236(2)$ & $0.238(1)$ & $0.238(1)$ & $0.242(2)$ & $0.2403(7)$ \\
\hline & $\mathrm{z}$ & $0.028(2)$ & $0.044(1)$ & $0.0460(7)$ & $0.0471(5)$ & $0.042(1)$ & $0.0476(3)$ \\
\hline & $\begin{array}{c}\text { Unit Cell } \\
\text { а }(\AA)\end{array}$ & $6.296(2)$ & $6.2925(9)$ & $6.2927(7)$ & $6.2930(4)$ & $6.2933(7)$ & $6.2933(2)$ \\
\hline & b $(\AA)$ & $6.293(6)$ & $6.296(2)$ & $6.2950(9)$ & $6.2953(7)$ & $6.297(2)$ & $6.2955(5)$ \\
\hline & c $(\AA)$ & $13.290(2)$ & $13.267(1)$ & $13.260(1)$ & $13.2591(7)$ & $13.263(1)$ & $13.2579(4)$ \\
\hline & $\alpha\left(^{\circ}\right)$ & $80.69(7)$ & $81.11(2)$ & 81.14(1) & $81.140(9)$ & $81.12(2)$ & $81.143(5)$ \\
\hline & $\beta\left(^{\circ}\right)$ & $86.35(6)$ & $86.40(2)$ & $86.408(8)$ & $86.414(8)$ & $86.40(2)$ & $86.418(5)$ \\
\hline & $\gamma\left({ }^{\circ}\right)$ & 89.98(8) & $90.03(2)$ & $90.021(6)$ & $90.019(3)$ & $90.04(3)$ & $90.028(7)$ \\
\hline & Volume $\left(\AA^{3}\right)$ & $518.6(2)$ & $518.20(7)$ & $517.95(4)$ & 517.97(3) & $518.27(6)$ & $517.97(2)$ \\
\hline & $\begin{array}{c}\text { Equatorial } \\
\text { Size }(\mu \mathrm{m})\end{array}$ & $0.0156(6)$ & $0.0384(3)$ & $0.075(3)$ & $0.104(5)$ & $0.050(2)$ & $0.177(9)$ \\
\hline & $\begin{array}{c}\text { Microstrain } \\
\text { (\%) }\end{array}$ & $1(1)$ & $1.2(3)$ & $1.0(1)$ & $0.5(2)$ & $3.0(5)$ & $0.2(1)$ \\
\hline & Rwp (\%) & 8.28 & 6.83 & 4.30 & 4.07 & 7.01 & 3.41 \\
\hline & $\begin{array}{c}\text { Goodness of } \\
\text { Fit (GOF) }\end{array}$ & 4.28 & 3.4 & 1.86 & 1.92 & 4.20 & 1.94 \\
\hline
\end{tabular}

